DOI: $10.20472 /$ TE.2015.3.1.005

\title{
TITLE: GLOBAL - TRANS - MULTI? CONTEMPORARY ART IN THE LECTURE ROOM
}

\section{WOJCIECH RUBIS, PAULINA TENDERA}

\begin{abstract}
:
The paper presents several, both methodological and personal, remarks on the didactics of academic subjects connected with art in higher education institutions. The main research question will be: is contemporary art (painting, installation art and film as well as music) created in the global, transcultural or multicultural domain? During classes, in the uterrances of students and lecturers, are these terms synonymous, close in meaning or contradictional? How does the selection of certain linguistic items in class affect the attitudes, values and contents we transfer to the students?

These issues are crucial because of the need to educate the contemporary viewer of art who will be able to take part in the culture of the 21st century in a conscious and mature way, both passively and actively.
\end{abstract}

\section{Keywords:}

education, globalism, transcultural society, multicultural society, art, language

\section{Authors:}

WOJCIECH RUBIS, Jagiellonian University, Poland, Email: w.rubis@gmail.com

PAULINA TENDERA, Jagiellonian University, Poland, Email: paulina.tendera@gmail.com

\section{Citation:}

WOJCIECH RUBIS, PAULINA TENDERA (2015). Title: Global - Trans - Multi? Contemporary art in the lecture room. International Journal of Teaching and Education, Vol. III(1), pp. 64-69.,

10.20472/TE.2015.3.1.005 


\section{Global - Trans - Multi? Contemporary art in the lecture room}

The main area discussed in the articte is contemporary art as a subject taught at higher education level including master's and bachelor's degree as well as doctoral studies. Inspired by our own academic and didactic experiences we would like to present a few selected observations regarding the use of three concepts crucial to the contemporary culture: multiculturalism, global culture and transculturalism. Our remarks are connected with our teaching activities, both in theoretical majors (courses on theory of art, aesthetics and philosophy of art) and in artistic majors: music education, graphics. It has been pointed out in many seminal publications that "in recent years in world education as well as in mass media we can observe the ever-growing interest in socio-cultural dynamics and interaction between contemporary civilizations. The causes of such an interest can, without a doubt, be found in the increasing globalization, in all of its aspects - economic, political and socio-cultural" (Świerzowska, 2013, p. 7). A number of important considerations presented in publications encourage building "intercultural competencies" with students, which should help develop a certain sensitivity to problems connected with the world's cultural diversity (Świerzowska, 2013, p. 7). Such a sensitivity can be developed through substantial knowledge, information regarding the geography of a given civilization, the social structure, economy, but first and foremost the intellectual and spiritual consistency which entails artistic creativity, art. Two aspects of intercultural sensitivity have proved to be crucial for us in this case, namely one which can be called the empathetic aspect, and the practical aspect. The former does not only require the capacity to respect and accept the manifestations of cultural diversity, but also - what is important for us with regards to art - the ability to partake in the spiritual and artistic realms of a given cultural circle. In the practical aspect, in turn, the emphasis is not put just on the ability to use the acquired knowledge to acheive certain economic and political goals, but also on building up the understanding of the sense and value of cultural, religious and artistic products of a given civilization.

A recurring question in our courses has been: is contemporary art (including painting, installation art, film and music) art created in the global, transcultural or multicultural domain? This question is not trivial, on the contrary, its anthropological, cultural aspect reveals meaningful cognitive dichotomies which might have their source in the language. The aformentioned question cannot be expected to have a univocal answer, unless it is one which states that contemporary art is created in all of these domains. This, however, would be an answer that could be seen as (1) biased as it is populistic - lacking evidence from any actual cultural research; (2) too general, as not every type of art and not every civilisation's evironment is equally open to fusion with elements from outside of themselves (which theoretically gives a possibility that a certain type of art could be described using the transcultural language, but at the same time it would be impossible to describe it using the language of globalisation; (3) an answer like that without any argumentation cannot convey any of its meaning which is most important in anthropological and cultural 
research (we will include a short discussion of this issue hereunder). Let us recall our main question: Is contemporary art (painting, installation art, film as well as music) created in the global, transcultural or multicultural domain? To begin with, let us think about where it comes from and how we can understand it.

\section{The issue of mixing up the meanings of the concepts:}

It is vital for us to note that in everyday, colloquial use of words "global", multi-" and "transcultural" it often occurs that the meanings of each of those overlap, switch around or are viewed as equivalent. While it is clearly impossble to completely outlaw the use of colloquial language during classes, as it is a natural element of communication with the students, using those concepts as words of similar meaning or synonyms is clearly a mistake. Furthermore, it is rarely pointed out that they can even be mutually exclusive (!). Thus, it is worth noting that mixing up the concepts and their fields of meanings is a significant methodological, didactic and, above all, an academic error. The concepts of culture of globalisation, multiculturalism and transculturalism differ greatly in meanings and - what is more important and proven by an in-depth analysis - they are used for different ways of describing, understanding and evaluating contemporary art. In effect, one cannot deny that even a subconscious selection of the language used in the course of classes influences the attitudes, the values and contents conveyed to the students. Let us point out a few important remarks and facts regarding the use of each of the three concepts:

The language of the culture of globalisation (which should not be confused with the global culture, as it is concerned with globalisation instead of the global aspect) is used mainly to communicate within the area of mass media and popculture (it is often English or the native language with certain elements of English, sometimes "the language of the internet", e.g from messengers), the elements of this language are also sometimes used in class. Globalisation itself is viewed quite broadly in this case, as a set of processes aimed at the integration and interdependence of cultures, societies or countries, processes which seek to create one global economy (Kempny, 1998, p. 241). The language which describes the culture created in the unified world has to be unified as well - as simplified as possible, clear and unambiguous, with as few characters as possible which are at the same time able to retain a relatively big amount of information. This information is simple (messages) and is not extended by symbolic contents. Within the space ruled by globalisation, art, as well as any other product, is subject to the rules of the capitalist market, which is why art (as a product) and artistic creation (as the process of production) should be described by means of language of the culture of globalisation. Nevertheless, not every type of art created nowadays is a product of globalisation to the same extent and not every type of art we might want to discuss in class is created today. Goods created at the beginning of the $20^{\text {th }}$ century are not products of capitalism to the same extent as works created today, and similarly - art created in Nebraska is not capitalist to the same degree as art created in New York or Singapur (in highly industrialized areas). 
Hence, while talking about the language of globalisation we can conclude that it is used for descriptions of the world of popculture, for example commercial movies and music, fashion, current trends, applied arts (on its aspects related to the psychology of colour, design, attractiveness, brand, visual identification), it is also often used on the internet (the internet is a perfect example of a global village). This language will also be used to describe products from outside of the "world of art": packaging, everyday objects, cuts and styles - all features which are subject to the rule of aestheticisation of everyday life.

Communication by means of language of the culture of globalisation is easy and clear (sometimes it is even restricted to a visual message, a symbol, a logo), but at the same time it limits the value and the sense of a work of art and its ability to convey deeper meanings. That is why it is used in reporting and descriptive utterances, but not so much in evaluative ones (the global culture has not formed the tools for value judgement of art itself, instead it assigns a different value to works of art as products - they have market prices). The possible examples of objects which can be described using language of globalisation in the courses on aesthetics and philosophy of art are: company logos (e.g. McDonald's, Apple), internationalized items of contemporary art, such as Duchamp's bottle dryer (as a product of popculture), the sculpture of an orange dog by Jeff Koons, etc.

By means of the multicultural language we point to an important enriching and interpersonal aspect of art as a carrier of a message. Multiculturalism can be brought down to an assumption that the contemporary society can (or maybe should) exist as a system of many, even contradicting, normative systems. This type of society is said to be realized in Great Britain, France and Germany, in the area of art, however, this notion does not have to overcome the crisis which seems to concern strictly the political and social multiculturalism (this refers to the widely understood social, religious and minority-related issues which concern many European countries)

Multicultural art is a good tool for promoting slogans which stand at the roots of the European Union: equality, solidarity, agreement and tolerance. Multicultural art consciously builds a patchwork of many diverse cultures, each of which brings something new (e. g. a new value) to the area of communication. This aspect is crucial in educating students towards a conscious life in social structures, which is why its use can be helpful in such majors as: pedagogy, cultural studies, cultural management or ethics, and other majors related to education. Multicultural language has a specific quality connected with performing value judgements, but the values preferred by it are secondary for art itself, in other words - multicultural language will rarely be used to talk about art in itself (about its artistic and aesthetic values).

By using the third type of language, namely the transcultural language we put emphasis on intelectual values and the possibilities (but also limits!) of transmission of religious, philosophical or emotional contents from one culture to another. Raising awareness of important and deep contents of local (nationally, religiously or timewise: historically) art is the main assumption and goal of transculturalism. However, it should be noted in advance that the complete methodology and tools of description for transcultural art have not yet been developed. There are a few significant centres 
for comparative studies in Europe and around the world, but the notion of transculturalism itself is still too young to allow for a clear designation of its area of interest and possibilities. The concept of transculturalism is younger than the concepts of both globalisation and multiculturalism.

Transculturalism (in comparison with globalisation and multiculturalism) is the most compatible with the language of theory of art and philosophy, transculturalism is open to methodological supplementation by other areas of research. Thus for example, to answer question about the mechanism of transmission of contents from one culture to another and the ways of unerstanding them, we can recall the classical theory of archetypes by Carl Jung and prove that symbols and contents of art created in different cultures have a common ground. That ground is the subconscious or the collective unconscious which guarantees the self-understanding of art.

The language of transcultural art is best suited for analyses of high, traditional, historical art, aimed at an intellectual reception, as it requires awarenes of what can and what cannot be conveyed or expressed in a language other than the native language of the artist (creator). This language is used not only in the course of indepth studies of art taking place in artistic majors and philosophy and history of art. In fact, it could be stated that in the $21^{\text {st }}$ century this language replaced the europocentric methodology, valid almost until the second half of the $20^{\text {th }}$ century. Let us then take a look at why it is so necessary and what previous shortcomings it compensates for.

If we were to analyse a wall painting from the tomb of the Egyptian queen Nefertari (and let us note that this example is very simple because of the universal character of knowledge about ancient Egyptian art) and would like to convey the most possibly relevant information, we would have to use transcultural language. The language of the culture of globalization might describe the image of god $\mathrm{Re}$ as an element of popculture (copied onto posters and refrigerator magnets), multicultural language, in turn, will help us become conscious of the egyptian culture as a part and a basis of our own culture and consciousness (however it could be difficult to talk about a factual and realistic influence of ancient paintings over somebody's personal attitude to life). It is only the transcultural language, which is in fact used in art research, that can give us the most complete description of a given work. The information from the area of history of art is accessible within the boundaries of any language, but transculturalism and comparative studies help the researchers realize the need to explore the roots of that art, give information about the religion, beliefs, convictions and philosophy underlying it.

\section{The communicative needs of specific areas of knowledge and education:}

The choice of language and manner of talking about art also depends on the specific type of classes we teach in, in other words - on our needs as educators. Different types of language will be used when we talk about topics related to:

- history of art, where we do not deal with opinions, but with information and historical sources, the descriptions, for the most part, pertain to a single culture and are not accesible in languages of different cultures (for example 
the differences between semantic fields of a single concept in different cultures, e.g. the words "purity", "sin") or in the symbols of different cultures; in those cases either traditional language (the language created by the European culture and still used nowadays: europocentric language) or transcultural language are the most suitable.

- philosophy of art, aesthetics, where we often have to do with value judgements of works of art - for which the traditional languages of european philosophical systems, e.g. Platonism are suited quite well;

- another language will be used for discussion in cultural studies and anthropology, where we often fall back on the methodology of humanistic studies and rarely perform strict evaluations of works of art, and instead focus on the description of a given object (not on, for example, teaching or creating a real aesthethic experience of it) and need a wide range of historical information;

- and yet a different one will be needed when teaching the basics of art criticism and in practical majors, where opinions and subjective remarks are valuable and significant, and free expression of one's own, different and personal comments is valued, as it develops eristics and the skill of voicing one's own views on art (rhetorics, eristics).

\section{Conclusions:}

The issues which were just designated in this presentation seem interesting to us because of the growing need to educate a contemporary art recipient, who will be able to take part in the area of culture of the $21^{\text {st }}$ century in a mature and conscious way, both passively (as a viewer) and actively (as a creator of art and culture - an artist). The challenges the contemporary world places before an academic teacher are not just about the need of the constant expansion of their theoretical knowledge, but also about openness and willingness to change the way of speaking about, describing and evaluating their subject of research - in this case art. The concept we present above combines both an openness to the changes in the research field and the work environment, and an attitude of respect towards traditional philosophy for which (as for most academic fields) methodological purity is a priority.

\section{References:}

1. Świerzowska A., "Wstęp", in: Porównawcze Studia Cywilizacji. The Polish Journal of The Arts and Culture, pod red. A. Świerzowska, A. Kowalska, B. Prochowicz-Studnicka, B. Gierek, Nr 3 (3/2013). Por. http://www.psc.uj.edu.pl/nauka/publikacje//journal_content/56_INSTANCE_sie1GCNmcwqN/30300043/39341709.

2. Kempny M., Globalizacja, in: Encyklopedia socjologii. Warsaw: Oficyna Naukowa, 1998. 